\title{
Sediment toxicity assessment using bacterial bioluminescence: effect of an unusual phytoplankton bloom
}

\author{
Nevenka Bihari ${ }^{1,}$, Mirjana Najdek ${ }^{1}$, Romina Floris ${ }^{1}$, Renato Batel ${ }^{1}$, Rudolf K. Zahn ${ }^{2}$ \\ ${ }^{1}$ Institute 'Ruder Bošković', Center for Marine Research, 52210 Rovinj, Yugoslavia \\ ${ }^{2}$ Commission for Molecular Biology, Academy of Sciences and Literature, 6500 Mainz, Federal Republic of Germany
}

\begin{abstract}
The toxicity of selected sediments in the Adriatic Sea and the effect of phytoplankton bloom on sediments in the vicinity of Rovinj, Yugoslavia, using bacterial bioluminescence toxicity assay, have been investigated. Sediments under the influence of urban and industrial wastes tend to be more contaminated than those in the open sea. The toxic effect of decayed material derived from sinking mucus aggregates was higher at locations influenced by local pollution. The time course study at 1 station suggested that increases in toxicity of sediment extracts is mainly due to changes in organic matter derived from decayed products of mucus aggregates.
\end{abstract}

During summer 1988, an intense nonseasonal phytoplankton bloom occurred in the Northern Adriatic (Degobbis in press) forming large mucus aggregates. The Istrian coast of the Northern Adriatic was fouled with large quantities of this mucus material. The nature of these aggregates is unknown, but most have associated pelagic and benthic organisms, empty shells, much detritus and bacteria. This event has been previously described in the waters of Rijeka Bay (Zanon 1931) and the Gulf of Trieste (Herndl 1988). Sinking of these aggregates transfers nutrients and decayed material from the surface mixed layer to the seafloor, causing a drastic decrease in the number of benthic organisms caused by mechanical events or anoxic conditions (Zavodnik 1977, Stachowitsch 1984). Sediments in the vicinity of Ravinj were covered 180 to $90 \%$ of whole area) with a 1 to $2 \mathrm{~cm}$ thick layer of decayed material.

Since 1987 our laboratory has dealt with a program for monitoring the local pollution. In order to determine any secondary effects of decayed material on sediments at 4 locations in the vicinity of Rovinj, the

- Addressee for correspondence bioluminescence toxicity assay was used. It is a rapid method of comparing and ranking the toxicity of organic extracts of contaminated sediments (Schiewe et al. 1985) and is a reliable screening technique for a variety of pollutants in sediments (Williams et al. 1986). The results of our assay exhibited a high degree of similarity with other sediment toxicity tests (Giesy et al. 1988) and hence this technique can be used as an exploratory screening test.

Materials and methods. The surface layer of sediment samples were collected by SCUBA divers from 11 locations (Fig. 1). About $500 \mathrm{~g}$ wet sediment was frozen at $-20^{\circ} \mathrm{C}$ and transported to laboratory. Dry weight was determined by heating $10 \mathrm{~g}$ aliquots at $105^{\circ} \mathrm{C}$ for $24 \mathrm{~h}$. The presence of total organic material (TOM) was estimated by weight loss after heating at $500^{\circ} \mathrm{C}$. Extractable organic material (EOM) was determinated according to Meyers et al. (1984). For the bioluminescence assay, $100 \mathrm{~g}$ wet $\mathrm{wt}$ of sediments were extracted with dichloromethane-methanol $(2: 1)$ as previously described by Schiewe et al. (1985). After several washings to remove methanol, dichloromethane extracts were evaporated to dryness and dissolved in dimethylsulfoxide (DMSO). Extraction blanks were prepared by the same procedure but without sediment. Water samples (2l) were extracted with dichloromethane, evaporated to dryness and dissolved in $1 \mathrm{ml}$ DMSO. Extraction blanks were prepared with distilled water.

Bacterial luminescence of a laboratory grown, healthy culture of the marine bacterium Photobacter phosphoreum will be inhibited upon exposure to toxic substances (Bulich \& Isenberg 1981). The luminescence of cultures exposed to a series of dilutions of sediment and water extracts was measured in a Packard-Tri-Carb 


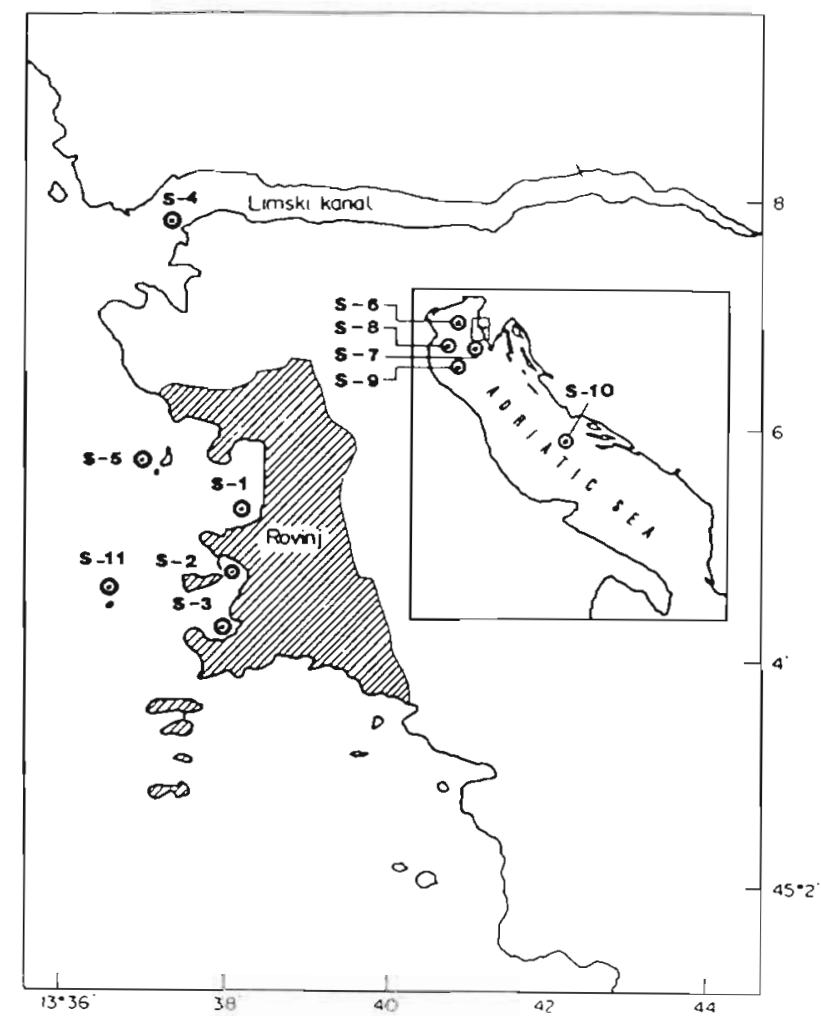

Fig. 1 Map of Rovinj, Northern Adriatic, showing sampling sites (S-1 to $\mathrm{S}-11$ )

liquid scintillation spectrometer. Briefly, in $0.5 \mathrm{ml}$ saline suspensions containing $10^{6}$ exponentially growing luminescent bacteria, $0.5 \mathrm{ml}$ of subsequent dilutions of sediment and water extracts in $2 \%$ saline were added. After $15 \mathrm{~min}$ incubation at $15^{\circ} \mathrm{C}$ the bioluminescence was measured, compared with blank samples, and corrected for spontaneous decline in photoactivity. The results are expressed as $\mathrm{mg}$ of dry weight of extracted sediments or $\mathrm{ml}$ of water causing a $50 \%$ reduction of bioluminescence in $15 \mathrm{~min}\left(\mathrm{ED}_{50}\right)$. Estimates of $E D_{50}$ were obtained using linear regression analysis, as described by Schiewe et al. (1985) and $95 \%$ confidence intervals for each estimate of $\mathrm{ED}_{50}$ were calculated based on Fieller's theorem (Finney 1964).

Results and discussion. Three of the 11 sample stations (Fig. 1), i.e., S-1, S-2, and S-3, are under the direct influence of industrial and/or urban runoff from a fish cannery, tobacco factory and urban waste, respectively. Comparison of toxicities of organic extracts of selected sediments and waters from the stations are presented in Table 1 Sediments influenced by urban sewage and industrial runoff tend to be more contaminated. The toxicity of waters directly influenced by industrial and urban wastes (S-1, S-2, S-3) were also higher than those of the open sea. However, this correlation, between the toxicity of sediment and water extracts was not observed at all stations.
Table 1. Comparison of toxicities of organic extracts of selected sediments (Sed., $\mathrm{mg}^{-1}$ dry wt) and waters (mg). ED $\mathrm{ED}_{50}$ : amount (mg dry wt or $\mathrm{ml} \mathrm{H}_{2} \mathrm{O}$ ) causing $50 \%$ reduction of biolummescence in $15 \mathrm{~min}$; ND: not determined; CI: confidence interval at $95 \%$ significance in parentheses

\begin{tabular}{|lrc|}
\hline Station & \multicolumn{2}{c}{ ED $_{50}$} \\
& Sed. & Water \\
\hline $\mathrm{S}-1$ & $0.9(0.6-1.3)$ & $1.1(0.8-1.3)$ \\
$\mathrm{S}-2$ & $1.5(1.2-2.9)$ & $0.3(0.2-0.7)$ \\
$\mathrm{S}-3$ & $3.2(1.9-3.8)$ & $0.6(0.4-1.0)$ \\
$\mathrm{S}-4$ & $5.6(3.8-7.5)$ & $\mathrm{ND}$ \\
$\mathrm{S}-5$ & $2.4(1.3-2.5)$ & $2.9(2.1-5.7)$ \\
$\mathrm{S}-6$ & $22.0(10-30)$ & $\mathrm{ND}$ \\
$\mathrm{S}-7$ & $29.0(10-30)$ & $4.8(2.6-5.2)$ \\
$\mathrm{S}-8$ & $13.0(10-20)$ & $\mathrm{ND}$ \\
$\mathrm{S}-9$ & $80.0(50-100)$ & $2.6(1.4-3.4)$ \\
$\mathrm{S}-10$ & $560.5(410-830)$ & $6.1(5.4-6.8)$ \\
$\mathrm{S}-11$ & $3.0(1.8-3.5)$ & $\mathrm{ND}$ \\
& & \\
\hline
\end{tabular}

The range in toxicity of sediment extracts is comparable to results obtained for Detroit River sediments (Giesy et al. 1988) and for Puget Sound sediments, Washington (Schiewe et al. 1985). Using our extraction procedure it was possible to analyse toxicity derived only from organic extractable pollutants. The contribution of some polar substances e.g. some classes of toxins produced by bacteria living in the sediments (Simidu et al. 1987. Kogure et al. 1988), as well as the bulk of metallic compounds, to sediment toxicity was excluded by the extraction procedure itself.

The toxicity of mucus material increased 15 -fold after $3 \mathrm{~d}$ incubation at $25^{\circ} \mathrm{C}\left(\mathrm{ED}_{50}\right.$ decreased from $4.2 \times 10^{-2}$ to $2.8 \times 10^{-3} \mathrm{ml}$ of mucus material), suggesting formation of toxic products during decay and biodegradation of mucus material in the laboratory. In order to investigate the possible influence of decayed material in the field, the toxicity of sediments at 4 locations, in the vicinity of Rovinj, were investigated after the mucus material sank. Two of the investigated locations (S-2 and S-3) which are directly influenced by urban sewage and industrial runoff were more impacted (Table 2). Since no toxic plankton bloom was detected in the investigation area, toxicity arose by either single classes of products (derived from large quantities of natural decayed material), or by contaminants scavenged from the water column. Extracts of water samples from heavily polluted areas showed 5 to 10 times higher toxicity (S-2 and S-3). However, at locations not directly influenced by local pollution (S-5 and $\mathrm{S}-11)$ the increase in sediment toxicity could be explained by the decay of mucus aggregates. A further explanation could be the increased remobilisation of contaminants from sediments caused by the additional impact of decayed material. Moreover, areas that have sediment of smaller grain size and higher organic con- 
Table 2. Comparison of toxicities or organic extracts of selected sediments before and after sinking of decayed material. ED 50 : amount (mg dry wt or $\mathrm{ml} \mathrm{H}_{2} \mathrm{O}$ ) causing $50 \%$ reduction of bioluminescence in $15 \mathrm{~min}$; $\mathrm{Cl}$ : confidence interval at $95 \%$ significance (in parentheses); Increase: $x$-fold increase in toxicity

\begin{tabular}{llccc|}
\hline Station & \multicolumn{2}{c|}{$\begin{array}{c}\text { ED } 50\left(\mathrm{mg}^{-1} \text { dry wt) }\right. \\
\text { After }\end{array}$} \\
\hline S-2 & Before & Increase \\
S-3 & Sandy & $1.5(0.9-1.9)$ & $9.2(7.1-14) \times 10^{-2}$ & 16 \\
S-5 & Sandy-silt & $3.2(1.9-3.8)$ & $4.7(4.3-8.6) \times 10^{-2}$ & 68 \\
S-11 & Muddy sand & $2.4(1.3-2.5)$ & $3.2(1.8-3.7) \times 10^{-1}$ & 7.5 \\
\end{tabular}

tent tend to become more contaminated (Knezovich et al. 1987), since these often correspond to the areas of greatest deposition.

In order to obtain a better understanding of such processes, the influence of decayed material on sediment from one location (S-11) over a period of 10 mo was investigated. A 10 -fold increase in the toxicity of sediments followed an increase in EOM (Fig. 2). This is in agreement with the measured increase in TOM caused

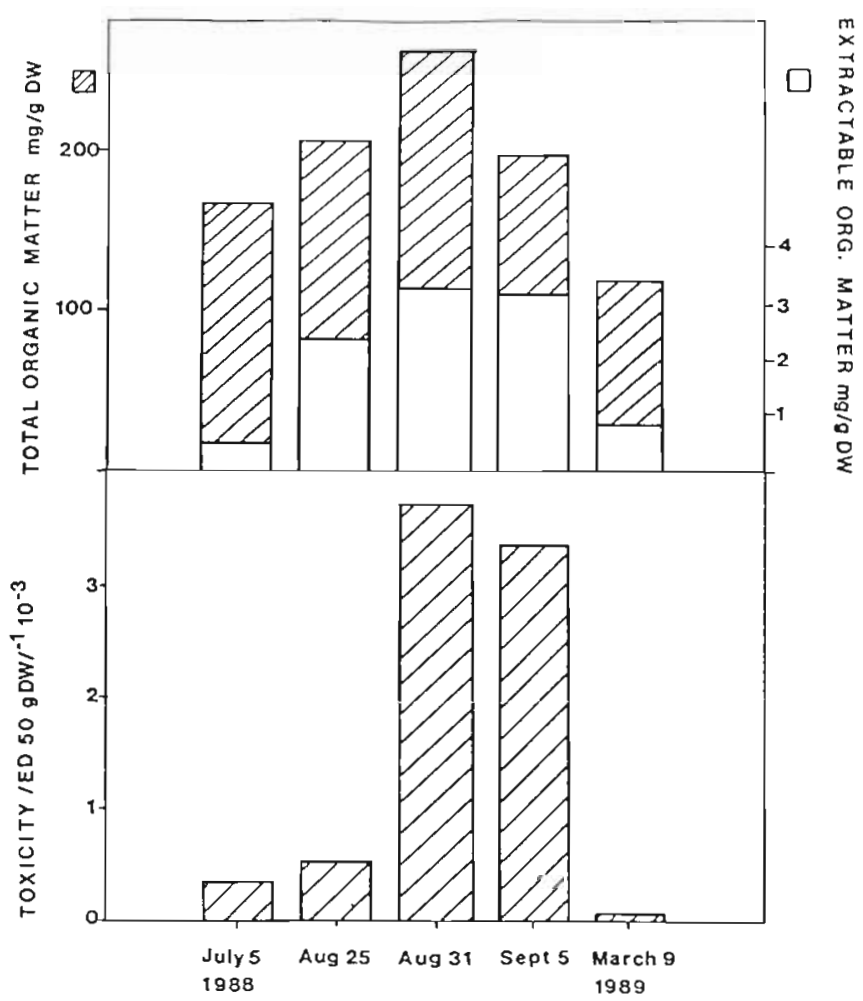

Fig. 2. Total and extractable organic matter content and toxicity of sediment extracts at Station S-11 during the phytoplankton bloom

by continuous sedimentation of decayed material. At the end of August the bulk of decayed material had settled into the sediment surface. No further increase in extractable organic matter and toxicity was observed. Six months later, both the EOM and toxicity decreased to the level measured prior to the bloom. These results suggested that the increase in toxicity of sediment extracts could be explained mainly as a consequence of changes in organic matter derived from the decayed products of mucus aggregates. The contribution of contaminants, scavenged from the water column and/or by remobilisation from sediments, to the increase in sediment toxicity has yet to be established.

Sediment meiofauna, in the vicinity of Rovinj, are sensitive to local point pollution (Vidakovic 1983) as further indicated by our results. Extrapolation of the increase in sediment toxicity, due to the decay of mucus material, to organisms living in the sediment is complex. The primary effect of mucus aggregates on living organisms in the sediment is on mechanical processes and anoxic conditions (Zavodnik et al. 1989). However, the secondary effect, i.e. of an increase in the toxicity of sediment organic matter as demonstrated here, must also be considered.

Acknowledgements. The authors would like to thank Staša Puškaric for his excellent help in collecting sediment samples. This study was financially supported by the Self-Management Community for Scientific Research of S.R. Croatia and by GKSS, Forschungszentrum Geesthacht GmbH, F.R. Germany. We gratefully acknowledge their help and support.

\section{LITERATURE CITED}

Bulich, A. A., Isenberg, D. L. (1981). Use of the luminescent bacterial system for the rapid assessment of aquatic toxicity. Trans. A.m. Instrument Soc. 20: 29-33

Degobbis, D. (1989). Increased eutrophication of the Northern Adriatic Sea - second act. Mar. Pollut. Bull. (in press)

Finney, D. J. (1964). Statistical methods in biological assay. Charles Griffin \& Company Ltd, London, p. 668

Giesy, J. P., Graney, R. L., Newsted, J. L., Rosiu, C. J., Benda, A. (1988). Comparison of three sediment bioassay methods using Detroit river sediments. Envir. Toxic. Chem. 7: $483-498$

Herndl, G. J. (1988). Ecology of amorphous aggregations (marine snow) in the Northern Adriatic Sea. II. Microbial density and activity in marine snow and its implication to overall pelagic processes. Mar. Ecol. Prog. Ser. 48: 265-275

Kogure, K., Do, H. K., Thuesen, E. V., Nanba, K., Ohwada, K. Simidu, U. (1988). Accumulation of tetrodotoxin in marine sediment. Mar. Ecol. Prog. Ser. 45: 303-305 
Knezovich, J. P., Harrison, F. L., Wilhelm, R, G. (1987). The bioavailability of sediment-sorbed organic chemicals: a review. Wat. Air Soil Pollut. 32: 233-245

Meyers, P. A., Kawka, O. E., Whitehead, D. R. (1984). Geolipid, pollen and diatom stratigraphy in postglacial lacustrine sediment. Org. Geochem. 6: 727-732

Schiewe, M. H., Hawk, E. G., Actor, D. I., Krahn, M. M. (1985). Use of bacterial bioluminescence assay to assess toxicity of contaminated marine sediments. Can. J. Fish aquat. Sci. 42: $1244-1248$

Simidu, U., Noguchi, T., Hwang, D. F., Shida, Y., Hashimoto, K. (1987). Marine bacteria which produce tetrodotoxin. Appl. envirl Microbiol. 53: 1714-1715

Stachowitsch, M. (1984). Mass mortality in the Gulf of Trieste: the course of community destruction. Pubbl. Staz. zool. Napoli (I: Mar. Ecol.) 5: 243-264

Vidaković, J. (1983). The influence of raw domestic sewage on

This note was submitted to the editor density and distributior of meiofauna. Mar Poll. Bull. 14: $84-88$

Williams, L. G., Chapman, P. M., Ginn, T G. (1986). A comparative evaluation of marine sediment toxicity using bacterial luminescence, oyster embryo and amphipod sediment bioassay. Mar envirl. Res. 19: 225-249

Zanon, V (1931). Esame di un campione di 'mare sporco' del Golfo di Fiume. Memorie della Pontifica Accademia Nazionale dei Lincei 15: 33

Zavodnik, D. (1977). Benthic communities in the Adriatic Sea: reflects of pollution. Thalassia jugosl. 13: 413-422

Zavodnik, D., Zavodnik, N., Hrs-Brenko, M., Jaklin, A., Zahtila, E. (1989). Neuobičajeni oblik eutrofikacije u Sjevernom Jadranu u 1988 godini 5. Posljedice na životne zajednice morskog dna Zapadne obale Istre. In: Jugoslavensko društvo za zaštitu voda (ed.) Konferencija zaštita voda 1989, I knjiga, p. 431-438

Manuscript first received: June 5, 1989

Revised version accepted: July 27, 1989 